\title{
Evaluation of commercial arrowroot starch/CMC film for buccal drug delivery of glipizide
}

\author{
Dhanasekaran Gayathri' and Lakshmanan Saraswathy Jayakumari*
}

\author{
${ }^{1}$ Department of Rubber \& Plastics Technology, Anna University, Madras Institute of Technology Campus, \\ Chennai, Tamil Nadu, India \\ *Isjayakumarimit@gmail.com
}

\begin{abstract}
In the present work, commercial arrowroot starch (AR starch) has been successfully used as a base material with sodium salt of carboxy methyl cellulose (CMC) for buccal drug delivery system. Different ratio of CMC and AR starch has been prepared with constant ratio of drug. In our study, glipizide has been used as the drug for controlled drug delivery through buccal mucosa. Films were cast by solution casting method with glycerol as plasticizer. All the films were characterized for thickness, swelling index, moisture content, relative $\mathrm{pH}$, drug content uniformity, compatibility of polymer and drug, surface morphology of films, muco adhesive property and in-vitro drug release study. Formulation F3 shows a residence time of 140 minutes with good mucoadhesive property, compatibility within polymers, drug content uniformity of $100 \pm 6.0 \%$ and a controlled drug release among all the ratios.
\end{abstract}

Keywords: arrowroot starch, buccal drug delivery, CMC, film, glipizide.

How to cite: Gayathri, D., \& Jayakumari, L. S. (2019). Evaluation of commercial arrowroot starch/CMC film for buccal drug delivery of glipizide. Polímeros: Ciência e Tecnologia, 29(4), e2019047. https://doi.org/10.1590/0104-1428.06619

\section{Indroduction}

The development of buccal drug delivery has been focused in recent years ${ }^{[1,2]}$ due to the advantages like controlled drug delivery, compatibility, rapid termination, flexibility, comfort, ease in accessibility, most convenient, easy and painless administration ${ }^{[3,4,5]}$. First pass hepatic metabolism is avoided in buccal drug delivery system as it access directly into the systemic circulation through jugular vein which makes more bioavailability than gastrointestinal route of drug release ${ }^{[6]}$. Mucoadhesive polymers are widely used as the base material to carry the drug and adhere to the mucosal surface of the buccal cavity ${ }^{[7]}$. Mucoadhesion is a process in which mucous membrane and the polymer get adhered ${ }^{[8]}$. In buccal drug delivery system, drugs can be administered in many forms such as ointments, patches, tablets, gels and films, but films are widely used because of its long residence time, flexibility, thinness, comfort and patient's compliance ${ }^{[9]}$.

Selection of suitable material is essential for the development of different drug dosage forms ${ }^{[10]}$. Many polymers such as polycarbophil, carbopol, hydroxy propyl methyl cellulose, hydroxy ethyl cellulose, alginate, sodium carboxymethyl cellulose, polyvinyl pyrrolidone and hydroxy propyl cellulose are widely used due to their mucoadhesion property, compatibility with drug, flexibility and film forming capacity ${ }^{[1-16]}$. The mechanism behind the interaction of mucus and mucoadhesive polymers results in physical entanglement, hydrogen bonding or Van-der-Waals attraction. The adhesion property mainly depends on the chemical groups present at the surface of the polymers such as hydroxyls, amines, amides and carboxyls ${ }^{[17-19]}$ Cellulose derivatives are considered to be a promising material in terms of mucoadhesion property and hydrogen bonding ability with mucous membrane. It has been reported that carboxymethylcelullose has good mucoadhesive property than other cellulose derivatives. Since CMC is an anionic polymer it has the ability to form hydrogen bonding but other derivatives like hydroxypropylmethylcellulose, which is non-ionic neutral derivative has a moderate mucoadhesive property due to the absence of proton donating carboxyl groups which facilitates the formation of hydrogen bonds ${ }^{[20,21]}$.

Starch is a natural biopolymer, which is widely available and low $\operatorname{cost}^{[22]}$. In drug delivery and tissue engineering starch have been widely used ${ }^{[23]}$. Starch films are usually brittle with more tackiness. Starch can be used as oral films when it is suitably formulated with mucoadhesive polymers like CMC, HPMC, chitosan ${ }^{[24,25]}$. In the case of starch, amylose and amylopectin content are crucial for its mechanical and thermal properties. Higher the amylose content, more strong the film will be. Amylopectin contributes to the flexibility of the film. Generally all kind of starches have about $25 \%$ of amylose and $75 \%$ of amylopectin content. Strength of the film, processability, ability to resist water and thermal stability depends upon the molecular weight.

When starch and CMC is blended it leads to improved mechanical properties in terms of increased tensile strength and decreased elongation at break ${ }^{[26,27]}$. CMC addition in starch increases the film forming properties of $\operatorname{starch}^{[28]}$ and blending of starch and CMC results in clearer film without hazy appearance ${ }^{[29]}$. CMC/starch forms a biodegradable 
film suitable for many applications such as edible film and coating, packaging and in some medical applications ${ }^{[26]}$.

Glipizide is a second generation sulphonyl urea based drug which stimulates the $\beta$ cells of pancreas to release insulin ${ }^{[30]}$. Glipizide is considered to be an antidiabetic drug with a biological half-life of $3-4 \mathrm{~h}$, such a rapid absorbing drug will also have fast elimination $\operatorname{rate}^{[31,32]}$. Although glipizide is a widely consumed antidiabetic drug, it leads to gastrointestinal disturbance on chronic usage ${ }^{[33]}$. Therefore it is necessary to formulate a material which entraps glipizide and facilitates controlled and sustained drug release without affecting gastrointestinal track.

In this present study, commercially available Indian arrowroot starch, which is low cost, has been effectively used as a matrix material for buccal drug delivery system. Glipizide, an anti-diabetic drug is successfully incorporated in the film with carboxymethylcellulose and Indian arrowroot starch to evaluate the basic film property, drug delivery efficacy, stability of the film and mucoadhesion property for buccal film, in vitro residence time and in vitro drug release.

\section{Experimental}

\subsection{Materials}

Sodium salt of carboxymethylcellulose with medium viscosity was purchased from Sigma Aldrich, Arrowroot starch (curcuma angustifolia) was purchased from local market in Chennai (harvested between March-April 2017) and glycerol was purchased from Fischer Scientific. Double distilled water was used throughout the process. All the chemicals were used as purchased.

\subsection{Amylose and amylopectin content of starch}

Amylose and amylopectin content in the arrowroot starch sample was determined using standard iodine calorimetric method according to ISO 6647-2 ${ }^{[34]}$. Percentage of amylose and amylopectin content was found to be $46.8 \%$ and $53.2 \%$ respectively.

\subsection{Preparation of drug loaded CMC/AR starch film}

Starch and CMC blends were formed with different weight ratios such as 100:0, 10:90, 30:70, 50:50, 70:30, 90:10 and 0:100 wt\%. Starch was gelatinized with $30 \mathrm{~g}$ of DI water at $90{ }^{\circ} \mathrm{C}$ for 15 minutes using magnetic stirrer with $300 \mathrm{rpm}$. CMC was dissolved in $100 \mathrm{~g}$ of water and made to stir for 2 hours to form a homogeneous solution. Gelatinized starch solution was cooled to room temperature and was mixed with CMC solution and stirred for another
10 minutes after adding $0.5 \mathrm{~g}$ of glycerol as the plasticizer. The above mixture was cast by solution casting method in a petri dish dried at $40{ }^{\circ} \mathrm{C}$ overnight in hot air oven. Different formulation of polymer and drug is given in the Table 1 .

\subsection{Film thickness and weight measurement}

The films of blend and the plain CMC and starch were cut into $2 \mathrm{~cm} \times 2 \mathrm{~cm}$ dimension and each formulation was weighed accurately with three specimens in each sample with the digital balance. The film thickness was measured using the (model Baker 10mm) dial thickness gauge K130/3, at minimum five different points ${ }^{[9]}$.

\subsection{Surface $\mathrm{pH}$ of films}

Surface $\mathrm{pH}$ of the film was determined by preparing a film specimen of a dimension $2 \mathrm{~cm} \times 2 \mathrm{~cm}$ and kept in the petri dish by wetting the film with $0.5 \mathrm{ml}$ of water and allowed to swell for 2 hours at room temperature, surface $\mathrm{pH}$ of the film was determined using $\mathrm{pH}$ paper. Acid or alkaline $\mathrm{pH}$ of the film may cause irritation to the mucosa therefore it is necessary to maintain the $\mathrm{pH}$ of the film around $7^{[35]}$.

\subsection{Swelling index}

The swelling properties of blended films were measured by percentage swelling index. The film was cut into $2 \mathrm{~cm} \times 2 \mathrm{~cm}$ dimension and its weight was measured accurately and denoted as $\mathrm{W}_{1}$. Then the film was placed in the petri dish containing $5 \mathrm{ml}$ of phosphate buffer solution with a $\mathrm{pH}$ of 6.8. The swollen film was removed from the petri dish carefully and was wiped with filter paper to remove the excess solvent from the film ${ }^{[1]}$. The weight of the film was weighed and denoted as $\mathrm{W}_{2}$.

Swelling index was calculated by using the following Equation 1:

$$
\% \text { Swelling }=\frac{W 2-W 1}{W 1} \times 100
$$

Where, $\mathrm{W}_{1}$ = initial weight of the film. $\mathrm{W}_{2}=$ weight of the swelled film.

\subsection{Folding endurance}

Folding endurance of the film was measured quantitatively by repeatedly folding a small strip with a dimension of $4 \mathrm{~cm}$ $\times 1 \mathrm{~cm}$ at $180^{\circ}$ plane at the same place until it break or folded 300 times without breaking. The number of times film was folded without breaking is calculated and considered to be the measure of folding endurance ${ }^{[5]}$.

Table 1. Formulation of AR starch/CMC blend system.

\begin{tabular}{ccccc}
\hline Ratio & CMC & Starch & Plasticizer & Drug \\
\hline $100: 0$ & $4.00 \mathrm{~g}$ & $0.00 \mathrm{~g}$ & $0.5 \mathrm{~g}$ & $0.5 \mathrm{~g}$ \\
$90: 10$ & $3.60 \mathrm{~g}$ & $0.40 \mathrm{~g}$ & $0.5 \mathrm{~g}$ & $0.5 \mathrm{~g}$ \\
$70: 30$ & $2.80 \mathrm{~g}$ & $1.20 \mathrm{~g}$ & $0.5 \mathrm{~g}$ & $0.5 \mathrm{~g}$ \\
$50: 50$ & $2.00 \mathrm{~g}$ & $2.00 \mathrm{~g}$ & $0.5 \mathrm{~g}$ & $0.5 \mathrm{~g}$ \\
$30: 70$ & $1.20 \mathrm{~g}$ & $2.80 \mathrm{~g}$ & $0.5 \mathrm{~g}$ & $\mathrm{~F} 2$ \\
$10: 90$ & $0.40 \mathrm{~g}$ & $3.60 \mathrm{~g}$ & $0.5 \mathrm{~g}$ & $\mathrm{~F} 3$ \\
$0: 100$ & $0.00 \mathrm{~g}$ & $4.00 \mathrm{~g}$ & $0.5 \mathrm{~g}$ & $0.5 \mathrm{~g}$ \\
\hline
\end{tabular}




\subsection{Moisture content}

The amount of moisture present in the film samples can be determined by simple weight measurement. $2 \mathrm{~cm} \times 2 \mathrm{~cm}$ dimension of each samples were cut and weighed as the initial weight $\left(\mathrm{W}_{1}\right)$. Then the samples were heated to $100{ }^{\circ} \mathrm{C}$ for nearly 2 hours to attain constant weight and it is considered as the final weight $\left(\mathrm{W}_{2}\right)$ of the sample. The percentage weight difference between $\mathrm{W}_{1}$ and $\mathrm{W}_{2}$ are the moisture content present in the film ${ }^{[36]}$.

\subsection{Drug content uniformity}

The drug content uniformity was measured by taking three specimens from each sample with a dimension of $2 \mathrm{~cm} \times 2 \mathrm{~cm}$ and dissolved in $100 \mathrm{~mL}$ of phosphate buffer solution with a $\mathrm{pH}$ of 6.8 and was continuously stirred for $6-8$ hours. The solution was filtered and diluted suitably and the drug content was measured in Varian Cary 50 UV spectrophotometer at an absorbance of $276 \mathrm{~nm}^{[37]}$. Drug content uniformity is measured by the following equation-

Drug Content uniformity = experimental drug loading/ theoretical drug loading $\times 100$.

\subsection{Drug - polymer compatibility study}

Drug and polymer interaction can be determined by using ATR-FTIR. The different formulation of blended film with drug content was analysed with the help of Attenuated total reflectance Fourier transform infrared spectroscopy of the model Bruker tensor 27 FTIR spectrometer (Bruker, Billerica, MA, USA) at a resolution of $4 \mathrm{~cm}^{-1}$ over the wave number region of $4000-400 \mathrm{~cm}^{-1}[15]$.

\subsection{Mucoadhesive property}

Mucoadhesion of polymer is important in buccal drug delivery system because it increases the residence time of the drug in the buccal cavity ${ }^{[38]}$. The buccal mucosa of goat was taken in phosphate buffer solution of $\mathrm{pH} 6.8$ and the polymer film was adhered on to the surface of mucosa, buccal mucosa and the film was taped in a glass substrate within the beaker containing phosphate buffer and allowed to stir at an RPM of 200 at $37^{\circ} \mathrm{C}$ using magnetic stirrer. Time taken by the film to detach from the mucosa is considered as the residence time and how long it attached to the mucosa gives the mucoadhesion property of the film ${ }^{[36]}$.

\subsection{Surface morphology studies}

Surface morphology and the presence of drug in the polymer film were studied by scanning electron microscopy using the model Hitachi S3400-N (Tokyo, Japan). All the films were gold coated using sputter coater. Films were analysed at an accelerating voltage of $20.0 \mathrm{kV}$ and at a resolution of $400 \mu \mathrm{m}$.

\subsection{In vitro drug release study}

In vitro drug release study was performed by adhering the polymer film in the side walls of the beaker which contains phosphate buffer solution with a $\mathrm{pH}$ of 6.8 , at a temperature of $37^{\circ} \mathrm{C}$. Assume that the drug releases from the film from one side only. Beaker was stirred gently in a magnetic stirrer and the buffer solution was sampled periodically in
Varian Cary $50 \mathrm{UV}$ spectrophotometer at $276 \mathrm{~nm}$ to find the concentration of drug present in the sample. Solution withdrawn from the beaker was then replaced with the exact volume at each sampling ${ }^{[39]}$.

\section{Results and Discussion}

\subsection{Film thickness and weight measurement}

Uniformity in film thickness is necessary because it is directly related to drug concentration and mucoadhesive property of the polymer. Plasticizer used in the formulation will affect the thickness of the film and sometimes even the polymer itself will increase the thickness of the film (polyvinylpyrrolidone). An ideal film for buccal drug delivery system should have an optimum thickness of around 0.05 to $1.0 \mathrm{~mm}^{[36,40]}$. Film thickness was measured at minimum five different points and mean standard deviation values has been calculated and is presented in Table.2. All films have a random thickness in the range of $0.22-0.32 \mathrm{~mm}$ irrespective of the ratio of polymers present in the film; it shows that polymer does not influence much in the thickness. PC, formulation measured a minimum thickness of $0.22 \mathrm{~mm}$ and $\mathrm{F} 1$ shows a maximum thickness of $0.32 \mathrm{~mm}$.

Weight measurements are generally done to ensure the uniform drug loading in the sample. Weight variations should not be larger as it renders inconsistency of drug loading ${ }^{[41]}$. Weight of the film is measured using digital balance and mentioned in the Table 2. Weight of the film also varies according to the moisture content present in the samples. Formulation F2 and F3 has a maximum film weight of 5.32 and $5.30 \mathrm{~g}$ respectively, this may be due to the presence of more moisture content in the film such as $24.6 \pm 1.25 \%$ and $23.1 \pm 0.72 \%$ for $\mathrm{F} 2$ and $\mathrm{F} 3$ respectively.

\subsection{Swelling ratio}

Swelling characteristic is one of the important factors which affect the mucoadhesive property of the polymers. The optimum amount of water uptake by the polymer film is essential in exhibiting mucoadhesive property ${ }^{[7]}$. Generally hydrophilic polymers will absorb more water and undergo dissolution by making pores, formation of such pores facilitates the diffusion of drug from the film ${ }^{[42]}$. Swelling is affected by structure of the polymer, temperature, swelling medium, ionic strength, $\mathrm{pH}$ of the environment and cross linking of network ${ }^{[43]}$. Polymers which have the ability to form hydrogen bonds can form a strong network structure, therefore penetration of water becomes difficult, and such hydrogen bond can be between polymer - polymer, polymer - plasticizer and polymer- drug ${ }^{[44,45]}$. In hydrophilic polymers like CMC swelling is mainly due to hydrogen bond formation between water and the polymer chain.

Starch contains readily available hydroxyl groups which attributes to the interaction of water and polymer chain for substantial hydrophilicity. Glycerol will also interact with polymer and water molecules, giving rise to hydrogen bonds and increase in swelling percentage ${ }^{[46]}$. In the present study constant amount of plasticizer and drug were used in all systems so, the interaction between drug - water and plasticizer - water does not influence much in swelling. PC formulation contain $\mathrm{CMC}$, plasticizer and 
Table 2. Physical properties of AR starch/CMC blend system.

\begin{tabular}{cccccccc}
\hline Formulation & $\begin{array}{c}\text { Thickness } \\
(\mathbf{m m})\end{array}$ & $\begin{array}{c}\text { Swelling } \\
\mathbf{( \% )}\end{array}$ & $\begin{array}{c}\text { Moisture } \\
\mathbf{( g )}\end{array}$ & Surface pH & $\begin{array}{c}\text { Film weight } \\
\mathbf{( g )}\end{array}$ & $\begin{array}{c}\text { Drug content } \\
\text { Uniformity } \\
(\mathbf{\%})\end{array}$ & $\begin{array}{c}\text { Folding } \\
\text { Endurance } \\
(\mathbf{N o})\end{array}$ \\
\hline PC & $0.22 \pm 0.01$ & dissolved & $2.90 \pm 0.05$ & $6.9 \pm 0.05$ & $4.86 \pm 0.05$ & $102 \pm 1.5 \%$ & $289 \pm 1.4$ \\
F1 & $0.32 \pm 0.02$ & $487 \pm 1.7$ & $3.90 \pm 0.05$ & $6.4 \pm 0.05$ & $4.93 \pm 0.06$ & $104 \pm 2.6 \%$ & $302 \pm 1.4$ \\
F2 & $0.23 \pm 0.01$ & $455 \pm 1.7$ & $24.6 \pm 1.25$ & $6.6 \pm 0.08$ & $5.31 \pm 0.05$ & $102 \pm 5.5 \%$ & $315 \pm 2.3$ \\
F3 & $0.24 \pm 0.01$ & $433 \pm 1.0$ & $23.1 \pm 0.72$ & $6.7 \pm 0.03$ & $5.29 \pm 0.03$ & $100 \pm 6.0 \%$ & $294 \pm 2.9$ \\
F4 & $0.28 \pm 0.05$ & $418 \pm 2.3$ & $15.0 \pm 0.58$ & $6.8 \pm 0.10$ & $5.09 \pm 0.03$ & $102 \pm 5.2 \%$ & $274 \pm 3.0$ \\
F5 & $0.27 \pm 0.03$ & $408 \pm 2.4$ & $12.1 \pm 0.44$ & $6.6 \pm 0.05$ & $5.07 \pm 0.05$ & $100 \pm 10.2 \%$ & $267 \pm 1.4$ \\
PS & $0.25 \pm 0.51$ & $355 \pm 2.8$ & $11.1 \pm 0.72$ & $6.9 \pm 0.05$ & $4.97 \pm 0.05$ & $104 \pm 7.3 \%$ & $252 \pm 1.4$ \\
\hline
\end{tabular}

drug, it swells faster and dissolve completely in the buffer solution of $\mathrm{pH} 6.8$ because the polymer interacts more with water than drug and plasticizer. In PS formulation $(355 \pm 2.8)$, which has AR starch, drug and plasticizer, has a considerable swelling percentage due to the interaction of AR starch with plasticizer and drug, therefore starch is not able to interact more with water to form hydrogen bond and does not dissolve so it swells in the presence of water. On increasing the percentage of AR starch in CMC, there is a gradual increase in swelling percentage in the formulations $\mathrm{F} 1(487 \pm 1.7), \mathrm{F} 2(455 \pm 1.7)$ and F3 (433 \pm 1.0$)$, this may be due to the synergistic interaction of CMC and AR starch with water in the film. In F4 (418 \pm 2.3$)$ and F5 (408 \pm 2.4$)$ swelling percentage tend to decrease as the less interacting AR starch has increased more (Table 2).

\section{$3.3 \mathrm{pH}$ of the film}

$\mathrm{pH}$ of the film is crucial in drug delivery system because the film should be compatible with the $\mathrm{pH}$ of the mucus surface which involved in absorbing the drug. $\mathrm{pH}$ is one of the factor which affects the mucoadhesion property of the polymer and therefore, optimum $\mathrm{pH}$ is necessary for required mucoadhesion ${ }^{[11,18]} . \mathrm{pH}$ of all the films are found to be in the range of saliva $\mathrm{pH}(6.5-6.8)$ and therefore it does not cause irritation at the place of administration ${ }^{[47]}$. $\mathrm{pH}$ of the film samples are given in the table.2.

\subsection{Drug content uniformity}

Drug content uniformity is important because it ensures that the drug is uniformly distributed throughout the film. The limit of drug content uniformity is likely to be between $85-115 \%{ }^{[48]}$. Drug content for all the samples was found to be between 100 to 105 (table.2).

\subsection{Moisture content}

Moisture content is essentially important as it helps in initial adhesion to the mucosa membrane. Optimum amount of moisture is needed to adhere the film to the mucosa membrane and excess moisture leads to tackiness in the film which leads to poor aesthetic appearance and difficulty in handling. $\mathrm{CMC}$ has more crystalline region than amorphous region in its molecular alignment. Therefore, it absorbs less moisture from the environment which appears in Formulation PC (CMC with drug) with least moisture content of $2.9 \pm 0.05^{[16]}$. AR starch after gelatinization becomes more amorphous and has porous structure and absorbs more moisture compared to CMC which is exhibited in the formulation PS (AR starch with drug) with $11.1 \pm 0.72$ of moisture content ${ }^{[49]}$. Formulation F1 (3.9 \pm 0.05$), F 2(24.6 \pm 1.25)$ and F3 (23.1 \pm 0.72$)$ shows a synergistic effect with the increased percentage of moisture with the gradual increment in the percentage of AR starch. Percentage of moisture present in the film samples was given in the Table 2 .

\subsection{Folding endurance}

Folding endurance value is expressed in terms of number of times the film is folded without breaking. Folding endurance value indirectly gives the mechanical property of the film, higher the folding endurance value, higher is the flexibility of the film ${ }^{[50]}$. The synergistic effect of CMC and AR starch shows an increase in the flexibility of the film in the Formulation F1 and F2 with an increased folding endurance value of 302 and 315 respectively.

\subsection{Drug - polymer compatibility study}

Compatibility between polymer and the drug is studied through FTIR. The FTIR spectrum of pure glipizide drug is shown in the Figure 1A. A vibrational stretch at $3340 \mathrm{~cm}^{-1}$ is attributed to the N-H bond present in the drug; similarly $2918 \mathrm{~cm}^{-1}, 1688 \mathrm{~cm}^{-1}, 1651 \mathrm{~cm}^{-1}$ and $1529 \mathrm{~cm}^{-1}$ are corresponding to $\mathrm{C}-\mathrm{H}$ stretching vibration, $\mathrm{C}=\mathrm{O}, \mathrm{C}=\mathrm{N}$ and $\mathrm{N}-\mathrm{H}$ bending vibrations respectively ${ }^{[51]}$ are observed. In Figure $1 \mathrm{~B}$, spectra of AR starch, CMC, and AR starch/CMC with drug are shown. AR starch film shows a stretching vibration at $3283 \mathrm{~cm}^{-1}$ due to the presence of hydroxyl group in AR starch as well as plasticizer (glycerol), $2928 \mathrm{~cm}^{-1}$ attributes to the presence of $\mathrm{C}-\mathrm{H}$ in the system. Peaks at $1015 \mathrm{~cm}^{-1}$ and $854 \mathrm{~cm}^{-1}$ are corresponding to the $\mathrm{C}-\mathrm{O}-\mathrm{C}$ stretching and bending vibrations present in AR starch respectively ${ }^{[52]}$.

CMC film shows a stretching vibration of hydroxyl group at $3276 \mathrm{~cm}^{-1}$ and presence of $\mathrm{C}-\mathrm{H}$ bond shows a characteristic peak at $2923 \mathrm{~cm}^{-1}$. Vibrational stretching present at $1589 \mathrm{~cm}^{-1}$ attributes to the $\mathrm{COO}^{-}$(carboxyl) group. A vibrational stretch at $1029 \mathrm{~cm}^{-1}$ attributes to the presence of C-O-C group in the film ${ }^{[53]}$. The blend film (starch-CMC with drug) shows no new characteristic peak in the spectrum, which means that $\mathrm{CMC}$, AR starch and glipizide drug are compatible without forming bonds between them. Blend film shows a broad peak between 3800 and $3000 \mathrm{~cm}^{-1}$ due to the presence of hydroxyl group in $\mathrm{AR}$ starch, $\mathrm{CMC}$, plasticizer and the stretching vibration of 
A

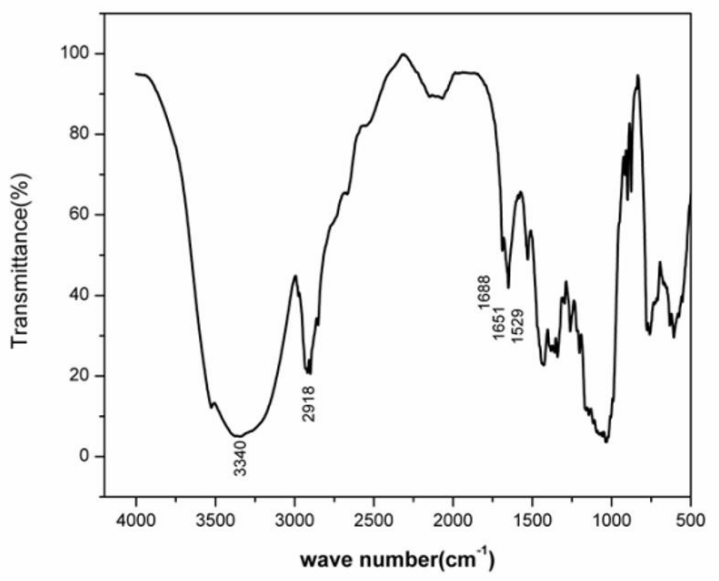

B

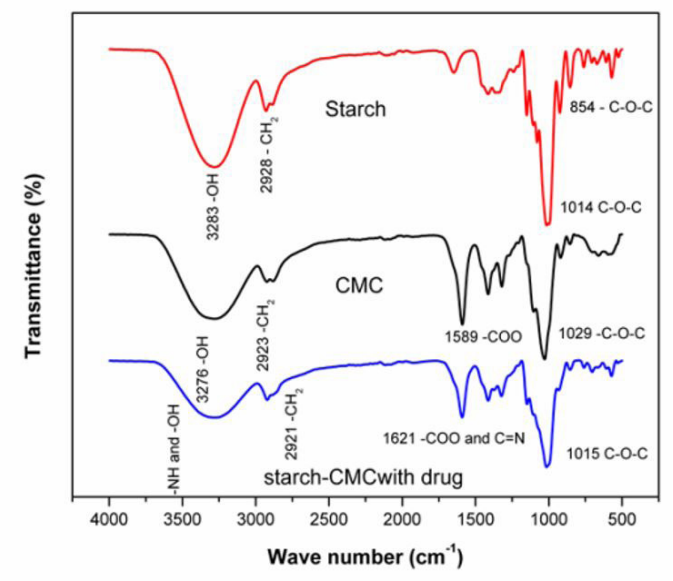

Figure 1. FTIR spectrum of glipizide (A), FTIR of starch, CMC and Starch-CMC and drug (B).

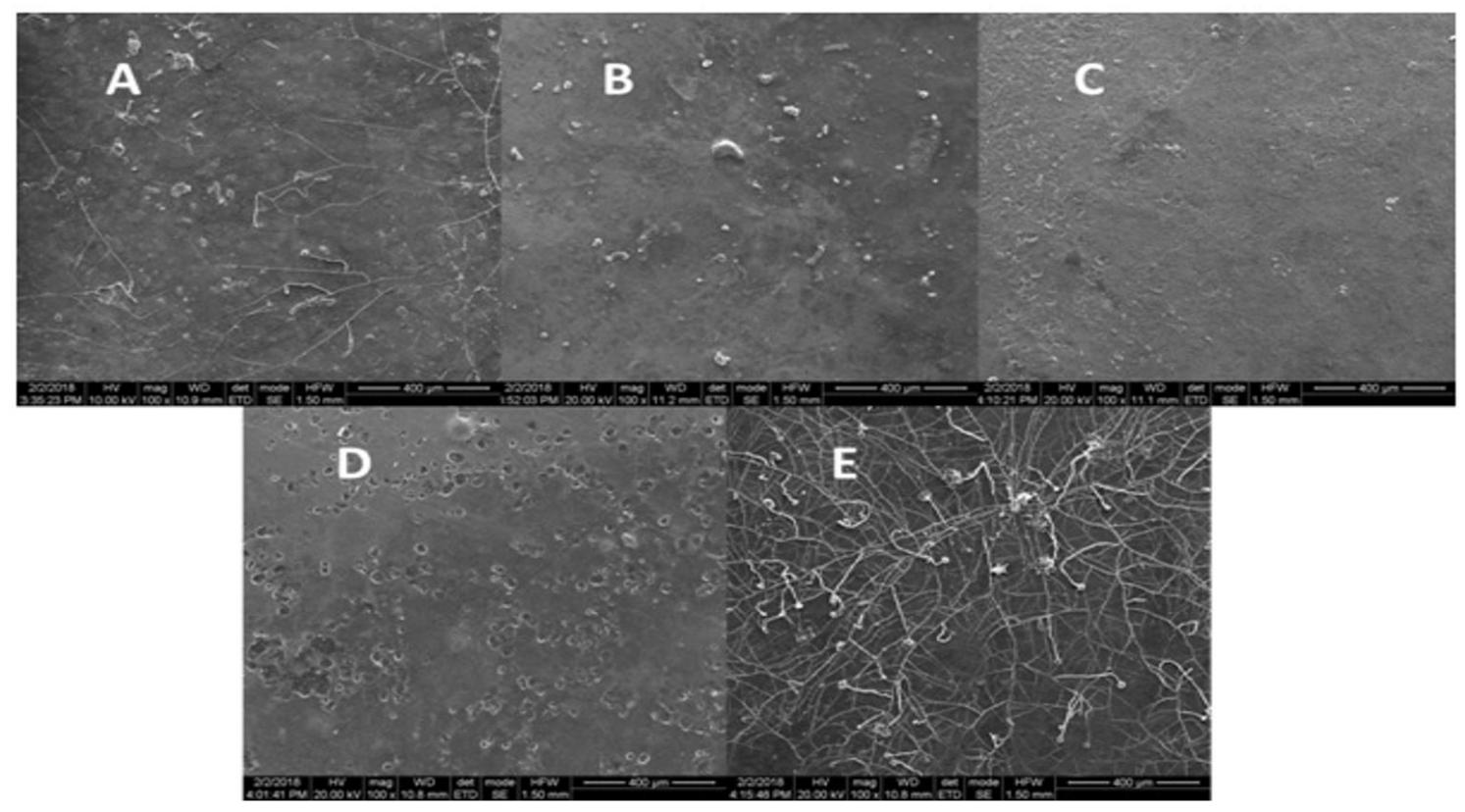

Figure 2. SEM image of different formulations F1(A), F2(B), F3(C), F4(D), F5(E).

$\mathrm{N}-\mathrm{H}$ group present in glipizide drug also overlaps to obtain a broad peak. Peak at $2921 \mathrm{~cm}^{-1}$ attributes to the $\mathrm{C}-\mathrm{H}$ present in $\mathrm{AR}$ starch, $\mathrm{CMC}$ and the drug. Vibrational stretching at $1621 \mathrm{~cm}^{-1}$ is corresponding to the overlap of $\mathrm{C}=\mathrm{N}$ present in the drug and $\mathrm{COO}^{-}$group present in $\mathrm{CMC}$. C-O-C stretching vibration in the spectrum is shown at $1015 \mathrm{~cm}^{-1}$ due to the presence of AR starch and CMC. All peaks appear in the blend of AR starch - CMC with glipizide drug with minor shift in the corresponding peak values.

\subsection{Scanning electron microscopy}

Scanning electron microscopy is a useful tool to analyse the surface morphology and compatibility of the blend system. It is also useful in studying the dispersion of drug present in the blend composition. Formulation of F1(Figure 2A) and F5(Figure 2E) shows a brittle morphology in the image attributing to the lack of plasticizer and insufficient amount of AR

and $\mathrm{CMC}$ in $\mathrm{F} 1$ and $\mathrm{F} 5$ respectively, but the presence of drug was found to be homogenous in both the images. Figure $2 \mathrm{~B}$ belongs to formulation F2, showing some agglomeration of drug in the surface but without any appearance of crack which may be due to the optimum percentage of plasticizer and adequate proportion of CMC and AR starch in the blend. Figure 2D also shows some agglomeration in the surface which belongs to $\mathrm{F} 4$ formulation. Figure $2 \mathrm{C}$ has optimum ratio of plasticizer, blend proportion and dispersion of drug is also homogenous which can be shown as smooth surface 


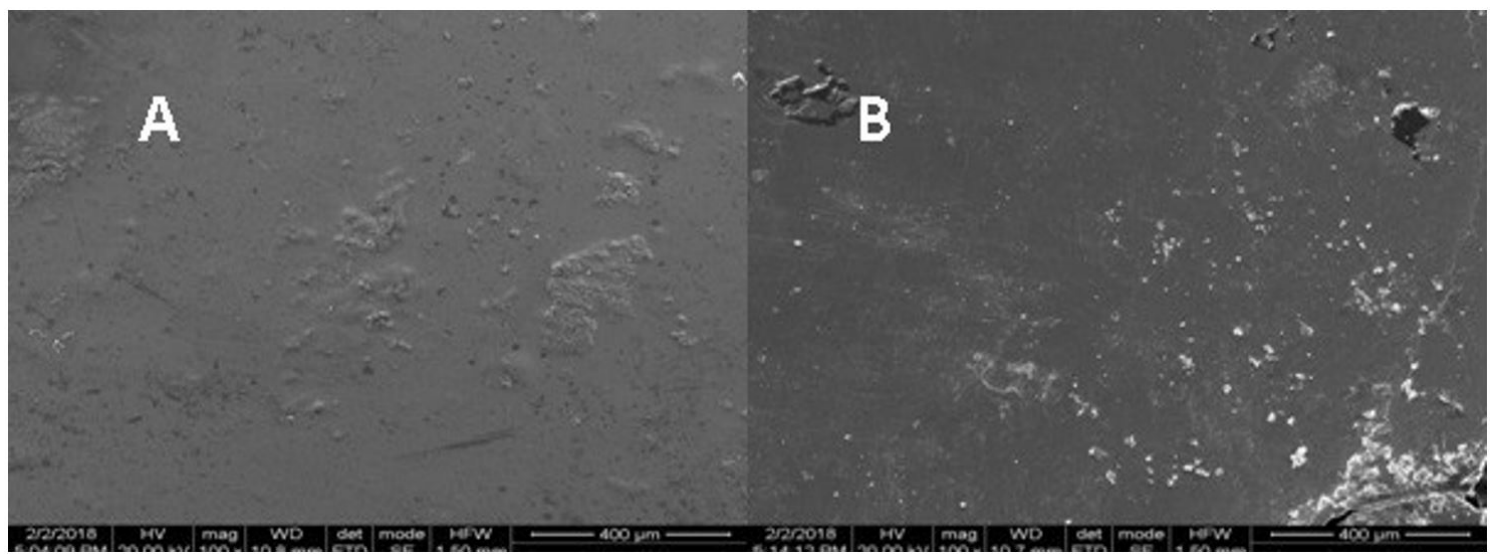

Figure 3. SEM image of Plain CMC with drug (A) and Plain AR starch with drug (B).

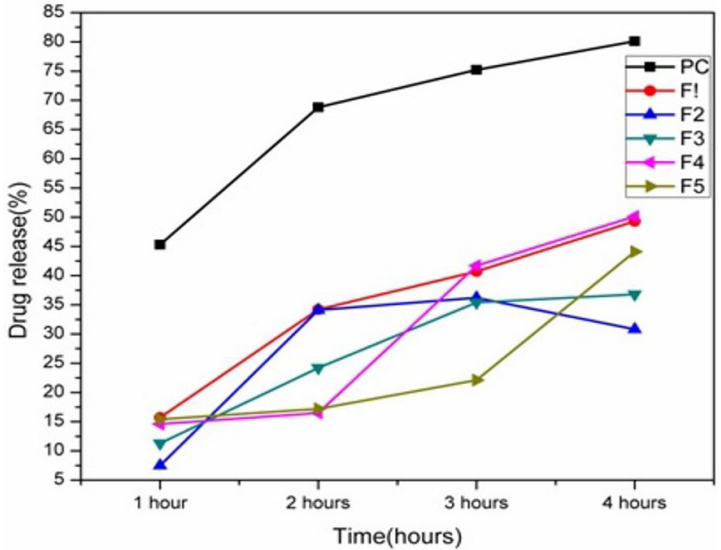

Figure 4. In-vitro drug release profile.

in the image, therefore F3 is considered as the optimum composition of polymer as well as the drug. Formulation $\mathrm{PC}$ and PS also shows some agglomeration of drug in the system which is shown in the Figure $3 \mathrm{~A}$ and $\mathrm{B}$.

\subsection{Mucoadhesive property}

Residence time of a film and mucoadhesive property is directly related to each other. In-vitro residence time of film in buccal mucosa of goat was examined and determined experimentally in minutes. F3 was found to have longest residence time of $140 \pm 3$ minutes and $\mathrm{F} 5$ has a least residence time of $30 \pm 2$ minutes. All the blend systems found to have mucoadhesive property with the mucosa membrane but the residence time differs between them according to the $\mathrm{wt} \%$ of polymer present in the system. CMC was reported to be a mucoadhesive polymer by many research groups ${ }^{[12,54,55]}$ therefore blend formulation with high proportion of CMC results in good mucoadhesive property. F1 and F2 initially swell faster when adhered to the surface of mucosa and dissolved within $80 \pm 3$ and $90 \pm 3$ minutes respectively. This may be due to the increased $\mathrm{wt} \%$ of hydrophilic CMC present in the system. At the same time F4 and F5 loosen the bond strength from the mucosa membrane within $40 \pm 2$ and $30 \pm 2$ minutes respectively because F4 and F5 has less proportion of $\mathrm{CMC}$ so the mucoadhesion property was low in those formulations. PS (AR starch with drug) has a residence time of less than 15 minutes, due to least mucoadhesive property of AR starch. F3 was found to have good mucoadhesive property and its residence time was $140 \pm 3$ minutes without dissolving in the buffer medium which attributes that $\mathrm{F} 3$ has an optimum composition of CMC and AR starch (50:50) as a mucoadhesive film.

\subsection{In vitro drug release study}

In-vitro drug release study was performed for 4 hours. Figure 4 demonstrates the drug release profile of different formulations. CMC has more affinity towards water than drug therefore it dissolves soon and releases the drug rapidly. This is also attributed in the swelling percentage of PC(dissolve). Formulation F1 (90:10) and F2 (70:30) shows a random release of drug which may be due to the presence of higher $\mathrm{CMC}$ ratio and non-uniform distribution of drug in the film and it is also confirmed by SEM image showing agglomeration and non-uniformity in the surface. PS has good interaction with $\mathrm{CMC}$, drug, plasticizer, which helps in entrapping drug for sustained release. But, drug release percentage was unable to study for PS, as it adhered to the side walls of the beaker due to least mucoadhesive property. All blend system shows mucoadhesive property and controlled drug release due to the synergistic effect of PC and PS. From the graph it implies that F3 (50:50) shows a sustained drug release at each hour compared to that of all formulations. So, F3 can be considered as an optimum formulation of the blend system with respect to drug release profile and SEM image also supports by homogenous, uniform and smooth surface (Figure 2C). F4 and F5 exhibit a random release of drug similar to $\mathrm{F} 1$ and $\mathrm{F} 2$ showing that the drug is non-uniformly distributed in the film.

\section{Conclusion}

In the present work, drug release through gastrointestinal route has been avoided and buccal route has been suggested because glipizide leads to gastrointestinal disturbance. In order to increase the residence time without losing the 
mucoadhesive property of CMC, AR starch is successfully blended with the constant ratio of antidiabetic drug, glipizide. Drug content uniformity of the films was found to be between 100 to $105 \%$. FTIR shows the compatibility between drug and the polymer materials. The smooth surface of the films by SEM also supports the compatibility of polymer and drug. Formulation F3 (50:50) was found to have suitable swelling ratio, smooth surface morphology, good muco- adhesive property and sustained in-vitro drug release profile. Therefore, the blend of commercially available, low cost Indian arrowroot starch and CMC can be used as buccal film for drug delivery system with suitable drug.

\section{Acknowledgements}

This Research work has been fully supported by (Anna Centenary Research fellowship) Anna University, Chennai. Authors also wish to thank the DST- FIST for the fund provided for the improvement of infrastructure in the Department.

\section{References}

1. Meher, J. G., Tarai, M., Yadav, N. P., Patnaik, A., Mishra, P., \& Yadav, K. S. (2013). Development and characterization of cellulose-polymethacrylate mucoadhesive film for buccal delivery of carvedilol. Carbohydrate Polymers, 96(1), 172-180. http:// dx.doi.org/10.1016/j.carbpol.2013.03.076. PMid:23688467.

2. Khan, S., Trivedi, V., \& Boateng, J. (2016). Functional physicochemical, ex vivo permeation and cell viability characterization of omeprazole loaded buccal films for paediatric drug delivery. International Journal of Pharmaceutics, 500(1-2), 217-226. http:// dx.doi.org/10.1016/j.ijpharm.2016.01.045. PMid:26802493.

3. Sabale, V., Paranjape, A., Patel, V., \& Sabale, P. (2017). Characterization of natural polymers from jackfruit pulp, calendula flowers and tara seeds as mucoadhesive and controlled release components in buccal tablets. International Journal of Biological Macromolecules, 95, 321-330. http://dx.doi. org/10.1016/j.ijbiomac.2016.11.078. PMid:27889336.

4. Pendekal, M. S., \& Tegginamat, P. K. (2012). Formulation and evaluation of a bioadhesive patch for buccal delivery of tizanidine. Acta Pharmaceutica Sinica. B, 2(3), 318-324. http:// dx.doi.org/10.1016/j.apsb.2011.12.012.

5. Sarojini S. (2016). Formulation development of Olmesartan Medoxomil Mucoadhesive buccal film. Asian Journal of Pharmaceutical Sciences, 10(4), 510-517. https://doi. org/10.22377/ajp.v10i04.886.

6. Khan, S., Boateng, J. S., Mitchell, J., \& Trivedi, V. (2015). Formulation, characterisation and stabilisation of buccal films for paediatric drug delivery of omeprazole. AAPS PharmSciTech, 16(4), 800-810. http://dx.doi.org/10.1208/s12249-014-0268-7. PMid:25559373.

7. Gök, M. K., Ozgumuş, S., Demir, K., Cirit, U., Pabuccuoglu, S., Cevher, E., Ozsoy, Y., \& Bacinoglu, S. (2016). Development of starch based mucoadhesive vaginal drug delivery systems for application in veterinary medicine. Carbohydrate Polymers, 136, 63-70. http://dx.doi.org/10.1016/j.carbpol.2015.08.079. PMid:26572329.

8. Semalty, M., Semalty, A., \& Kumar, G. (2008). Formulation and characterization of mucoadhesive buccal films of glipizide. Indian Journal of Pharmaceutical Sciences, 70(1), 43-48. http:// dx.doi.org/10.4103/0250-474X.40330. PMid:20390079.

9. Kraisit, P., Limmatvapirat, S., Luangtana-Anan, M., \& Sriamornsak, P. (2017). Buccal administration of mucoadhesive blend films saturated with propranolol loaded nanoparticles.
Asian Journal of Pharmaceutical Sciences, 13(1), 34-43. http:// dx.doi.org/10.1016/j.ajps.2017.07.006. PMid:32104376.

10. Nazari, K., Kontogiannidou, E., Ahmad, R. H., Andreadis, D., Rasekh, M., Bouropoulos, N., van Der Merwe, S. M., Chang, M. W., Fatouros, D. G., \& Ahmad, Z. (2017). Fibrous polymeric buccal film formulation, engineering and bio-interface assessment. European Polymer Journal, 97, 147-172. http:// dx.doi.org/10.1016/j.eurpolymj.2017.09.046.

11. Ch'ng, H. S., Park, H., Kelly, P., \& Robinson, J. R. (1985). Bioadhesive polymers as platforms for oral controlled drug delivery II: synthesis and evaluation of some swelling, water-insoluble bioadhesive polymers. Journal of Pharmaceutical Sciences, 74(4), 399-405. http://dx.doi.org/10.1002/jps.2600740407. PMid:3998999.

12. Ahuja, A., Khar, R. K., \& Ali, J. (1997). Mucoadhesive drug delivery systems. Drug Development and Industrial Pharmacy, 23(5), 489-515. http://dx.doi.org/10.3109/03639049709148498.

13. Okeke, O. C., \& Boateng, J. S. (2016). Composite HPMC and sodium alginate based buccal formulations for nicotine replacement therapy. International Journal of Biological Macromolecules, 91, 31-44. http://dx.doi.org/10.1016/j. ijbiomac.2016.05.079. PMid:27222284.

14. Dekina, S., Romanovska, I., Ovsepyan, A., Tkach, V., \& Muratov, E. (2016). Gelatin/carboxymethyl cellulose mucoadhesive films with lysozyme: Development and characterization. Carbohydrate Polymers, 147, 208-215. http://dx.doi.org/10.1016/j. carbpol.2016.04.006. PMid:27178926.

15. Diaz del Consuelo, I., Falson, F., Guy, R. H., \& Jacques, Y. (2007). Ex vivo evaluation of bioadhesive films for buccal delivery of fentanyl. Journal of Controlled Release, 122(2), 135-140. http://dx.doi.org/10.1016/j.jconrel.2007.05.017. PMid:17688966.

16. Kumar, V., \& Banker, G. S. (1993). Chemically-modified celldlosic polymers. Drug Development and Industrial Pharmacy, 19(1-2), 1-31. http://dx.doi.org/10.3109/03639049309038760.

17. Eouani, C., Piccerelle, P., Prinderre, P., Bourret, E., \& Joachim, J. (2001). In-vitro comparative study of buccal mucoadhesive performance of different polymeric films. European Journal of Pharmaceutics and Biopharmaceutics, 52(1), 45-55. http:// dx.doi.org/10.1016/S0939-6411(01)00146-1. PMid:11438423.

18. Duchene, D., Touchard, F., \& Peppas, N. A. (1998). Pharmaceutical and medical aspects of bioadhesive systems for drug administration. Drug Development and Industrial Pharmacy, 14(1), 283-318. http://dx.doi.org/10.3109/03639048809151972.

19. Mortazavi, S. A., Carpenter, B. G., \& Smart, J. D. (1993). A comparative study on the role played by mucus glycoproteins in the rheological behaviour of the mucoadhesive/mucosal interface. International Journal of Pharmaceutics, 94(1-3), 195-201. http://dx.doi.org/10.1016/0378-5173(93)90024-A.

20. Russo, E., Selmin, F., Baldassari, S., Gennari, C. G., Caviglioli, G., Cilurzo, F., Minghetti, P., \& Parodi, B. (2016). A focus on mucoadhesive polymers and their application in buccal dosage forms. Journal of Drug Delivery Science and Technology, 32, 113-125. http://dx.doi.org/10.1016/j.jddst.2015.06.016.

21. Parodi, B., Russo, E., Gatti, P., Cafaggi, S., \& Bignardi, G. (1999). Development and in vitro evaluation of buccoadhesive tablets using a new mode substrate for bioadhesion measures: The eggshell membrane. Drug Development and Industrial Pharmacy, 25(3), 289-295. http://dx.doi.org/10.1081/DDC100102173. PMid:10071821.

22. Xie, F., Halley, P. J., \& Avérous, L. (2012). Rheology to understand and optimize processibility, structures and properties of starch polymeric materials. Progress in Polymer Science, 37(4), 595623. http://dx.doi.org/10.1016/j.progpolymsci.2011.07.002.

23. Xiao, H., Yang, T., Lin, Q., Liu, G. Q., Zhang, L., Yu, F., \& Chen, Y. (2016). Acetylated starch nanocrystals: preparation 
and antitumor drug delivery study. International Journal of Biological Macromolecules, 89, 456-464. http://dx.doi. org/10.1016/j.ijbiomac.2016.04.037. PMid:27156696.

24. Koch, K., Gillgren, T., Stading, M., \& Andersson, R. (2010). Mechanical and structural properties of solution-cast highamylose maize starch films. International Journal of Biological Macromolecules, 46(1), 13-29. http://dx.doi.org/10.1016/j. ijbiomac.2009.10.002. PMid:19828118.

25. Borges, A. F., Silva, C., Coelho, J. F., \& Simões, S. (2015). Oral films: current status and future perspectives: I-galenical development and quality attributes. Journal of Controlled Release, 206, 1-19. http://dx.doi.org/10.1016/j.jconrel.2015.03.006. PMid:25747406.

26. Tongdeesoontorn, W., Mauer, L. J., Wongruong, S., Sriburi, P., \& Rachtanapun, P. (2011). Effect of carboxymethyl cellulose concentration on physical properties of biodegradable cassava starch-based films. Chemistry Central Journal, 5(1), 6. http:// dx.doi.org/10.1186/1752-153X-5-6. PMid:21306655.

27. Ghanbarzadeh, B., Almasi, H., \& Entezami, A. (2011). Improving the barrier and mechanical properties of corn starch-based edible films: effect of citric acid and carboxymethyl cellulose. Industrial Crops and Products, 33(1), 229-235. http://dx.doi. org/10.1016/j.indcrop.2010.10.016.

28. Kibar, E. A., \& Us, F. (2013). Thermal, mechanical and water adsorption properties of corn starch-carboxymethylcellulose/ methylcellulose biodegradable films. Journal of Food Engineering, 114(1), 123-13. http://dx.doi.org/10.1016/j. jfoodeng.2012.07.034.

29. Ghanbarzadeh, B., Almasi, H., \& Entezami, A. (2010). Physical properties of edible modified starch/carboxymethyl cellulose films. Innovative Food Science \& Emerging Technologies, 11(4), 697-702. http://dx.doi.org/10.1016/j.ifset.2010.06.001.

30. Gu, Q., Wang, C., Wang, G., Han, Z., Li, Y., Wang, X., Li, J., Qi, C., Xu, T., Yang, X., \& Wang, L. (2015). Glipizide suppresses embryonic vasculogenesis and angiogenesis through targeting natriuretic peptide receptor A. Experimental Cell Research, 33(2), 261-272. http://dx.doi.org/10.1016/j.yexcr.2015.03.012. PMid:25823921.

31. Seenivasan, P., Chowdary, K. P., Reddy, C. U., \& Murthy, J. S. (2013). Design and evaluation of glipizide CR tablets employing starch acetate as rate controlling matrix former. Journal of Pharmacy Research, 6(6), 653-655. http://dx.doi. org/10.1016/j.jopr.2013.06.013.

32. Sankalia, J. M., Sankalia, M. G., \& Mashru, R. C. (2008). Drug release and swelling kinetics of directly compressed glipizide sustained-release matrices: establishment of level A IVIVC. Journal of Controlled Release, 129(1), 49-58. http://dx.doi. org/10.1016/j.jconrel.2008.03.016. PMid:18456362.

33. Chowdary, K. R., Rao, N. K., \& Malathi, K. (2004). Ethyl cellulose microspheres of glipizide: Characterization, in vitro and in vivo evaluation. Indian Journal of Pharmaceutical Sciences, 66(4), 412-416.

34. International Organization for Standardization - ISO. (2007). ISO 6647-2. Rice - Determination of Amylose Content - Part 2: Routine Methods. Geneva: ISO.

35. Gajdosova, M., Vetchy, D., Dolezel, P., Gajdziok, J., Landova, H., Muselík, J., Zeman, J., Knotek, Z., Hauptman, K., \& Jekl, V. (2016). Evaluation of mucoadhesive oral films containing nystatin. Journal of Applied Biomedicine, 14(4), 247-256. http://dx.doi.org/10.1016/j.jab.2016.05.002.

36. Nair, A. B., Kumria, R., Harsha, S., Attimarad, M., Al-Dhubiab, B. E., \& Alhaider, I. A. (2013). In vitro techniques to evaluate buccal films. Journal of Controlled Release, 166(1), 10-21. http:// dx.doi.org/10.1016/j.jconrel.2012.11.019. PMid:23219961.

37. Li, X. Q., Ye, Z. M., Wang, J. B., Fan, C. R., Pan, A. W., Li, C., \& Zhang, R. B. (2017). Mucoadhesive buccal films of tramadol for effective pain management. Revista Brasileira de Anestesiologia, 67(3), 231-237. http://dx.doi.org/10.1016/j. bjan.2016.10.006. PMid:27899200.

38. Davidovich-Pinhas, M., \& Bianco-Peled, H. (2010). Mucoadhesion: a review of characterization techniques. Expert Opinion on Drug Delivery, 7(2), 259-271. http://dx.doi. org/10.1517/17425240903473134. PMid:20095946.

39. Hunt, J. A., Joshi, H. N., Stella, V. J., \& Topp, E. M. (1990). Diffusion and drug release in polymer films prepared from ester derivatives of hyaluronic acid. Journal of Controlled Release, 12(2), 159-169. http://dx.doi.org/10.1016/0168-3659(90)90092-8.

40. Cao, N., Yang, X., \& Fu, Y. (2009). Effects of various plasticizers on mechanical and water vapor barrier properties of gelatin films. Food Hydrocolloids, 23(3), 729-735. http://dx.doi. org/10.1016/j.foodhyd.2008.07.017.

41. Karki S., Kim H., Na S.J., Shin D., Jo K., Lee J. (2016). Thin films as an emerging platform for drug delivery. Asian Journal of Pharmaceutical Sciences, 11(5), 559-574. https:// doi.org/10.1016/j.ajps.2016.05.004.

42. Shidhaye, S. S., Saindane, N. S., Sutar, S., \& Kadam, V. (2008). Mucoadhesive bilayered patches for administration of sumatriptan succinate. AAPS PharmSciTech, 9(3), 909-916. http://dx.doi.org/10.1208/s12249-008-9125-x. PMid:18679806.

43. Peppas, N. A., Bures, P., Leobandung, W., \& Ichikawa, H. (2000). Hydrogels in pharmaceutical formulations. European Journal of Pharmaceutics and Biopharmaceutics, 50(1), 27-46. http://dx.doi. org/10.1016/S0939-6411(00)00090-4. PMid:10840191.

44. Baranowski, P., Karolewicz, B., Gajda, M., \& Pluta, J. (2014). Ophthalmic drug dosage forms: characterisation and research methods. TheScientificWorldJournal, 2014, 1-14. http://dx.doi. org/10.1155/2014/861904. PMid:24772038.

45. Panomsuk, S. P., Hatanaka, T., Aiba, T., Katayama, K., \& Koizumi, T. (1996). A study of the hydrophilic cellulose matrix: effect of drugs on swelling properties. Chemical \& Pharmaceutical Bulletin, 44(5), 1039-1042. http://dx.doi. org/10.1248/cpb.44.1039.

46. Mali, S., Sakanaka, L. S., Yamashita, F., \& Grossmann, M. V. (2005). Water sorption and mechanical properties of cassava starch films and their relation to plasticizing effect. Carbohydrate Polymers, 60(3), 283-289. http://dx.doi. org/10.1016/j.carbpol.2005.01.003.

47. Reddy, J. R., Muzib, Y. I., \& Chowdary, K. P. (2013). Development and in-vivo characterization of novel trans buccal formulations of Amiloride hydrochloride. Journal of Pharmacy Research, 6(6), 647-652. http://dx.doi.org/10.1016/j.jopr.2013.04.051.

48. Bhyan, B., Jangra, S., Kaur, M., \& Singh, H. (2011). Orally fast dissolving films: innovations in formulation and technology. International Journal of Pharmaceutical Sciences Review and Research, 9(2), 50-57.

49. Duan, X., Han, Y., Li, Y., \& Chen, Y. (2014). Improved capacity retention of low cost sulfur cathodes enabled by a novel starch binder derived from food. RSCAdvances, 4(105), 60995-61000. http://dx.doi.org/10.1039/C4RA10953H.

50. Irfan, M., Rabel, S., Bukhtar, Q., Qadir, M. I., Jabeen, F., \& Khan, A. (2016). Orally disintegrating films: a modern expansion in drug delivery system. Saudi Pharmaceutical Journal, 24(5), 537-546. http://dx.doi.org/10.1016/j.jsps.2015.02.024. PMid:27752225.

51. Joshi A. S., Patil C. C., Shiralashetti S. S., Kalyane N. V. (2013). Design, characterization and evaluation of Eudragit microspheres containing glipizide. Drug Invention Today, 5(3), 229-234. https://doi.org/10.1016/j.dit.2013.06.009.

52. Sandoval Gordillo, C. A., Valencia, G. A., Vargas Zapata, R. A., \& Agudelo Henao, A. C. (2014). Physicochemical characterization of arrowroot starch (Maranta arundinacea linn) and glycerol/arrowroot 
starch membranes. International Journal of Food Engineering, 10(4), 727-735. http://dx.doi.org/10.1515/ijfe-2014-0122.

53. Biswal, D. R., \& Singh, R. P. (2004). Characterisation of carboxymethyl cellulose and polyacrylamide graft copolymer. Carbohydrate Polymers, 57(4), 379-387. http://dx.doi. org/10.1016/j.carbpol.2004.04.020.

54. Jiménez-castellanos, M. R., Zia, H., \& Rhodes, C. T. (1993). Mucoadhesive drug delivery systems. Drug Development and Industrial Pharmacy, 19(1-2), 143-194. http://dx.doi. org/10.3109/03639049309038765.
55. Jimenez-Castellanos, M. R., Zia, H., \& Rhodes, C. T. (1993). Assessment of an in vitro method for measuring the bioadhesiveness of tablets. International Journal of Pharmaceutics, 89(3), 223-228. http://dx.doi.org/10.1016/03785173(93)90247-D. 